\title{
FPR1 wt Allele
}

National Cancer Institute

\section{Source}

National Cancer Institute. FPR1 wt Allele. NCI Thesaurus. Code C51444.

Human FPR1 wild-type allele is located in the vicinity of 19q13.4 and is approximately $6 \mathrm{~kb}$ in length. This allele, which encodes fMet-Leu-Phe receptor protein, plays a role in chemotaxis and neutrophil activation. 